\title{
Digitisation or Digitalisation: Diverse Practices of the Distance Education Period in Finland
}

Tiina Korhonen ${ }^{* 1}$, LeEnU JUUROla ${ }^{2}$, LAUra SALO ${ }^{2}$ AND

JoHANna AIRAKSINEN ${ }^{2}$

$\approx$ This case study explores how Finnish primary school teachers orchestrated school days and how teachers and headmasters organised virtual workplace collaboration and collaborated with parents during a period of distance education forced by the Covid-19 crisis in Spring 2020. The data was collected by interviewing primary and secondary school teachers $(n=15)$ from eight schools in various parts of Finland. Teachers' experiences were analysed with qualitative content analysis. In this study, the school is seen as a Complex Adaptive System (CAS) and the Covid-19 crisis as a disorder forcing teachers to adapt to a rapidly changing environment. Teachers are viewed here as innovators who address both pedagogical and digital challenges under abnormal circumstances. We identify diverse practices at different stages of digitalisation during the distance education period within four domains: 1) structures of school days, 2) forms of teaching, 3) collaborative activities of teachers and headmaster, and 4) forms of home and school collaboration. We also identify three groups of enablers of distance education practices: 1) the use of digital technology, 2) digipedagogical competence of the teachers, and 3 ) the ability of teachers to act as adaptive innovators. We find that teachers' ability to innovate and to adapt pedagogical and digipedagogical expertise become critical success factors when change is forced upon the educational field. We suggest that the results of this study, portrayed as the enablers and domains of distance education, be utilised in planning post-Covid education. All stakeholders influencing schools at different levels should be included in envisioning and implementing future classroom practices of innovative post-Covid schools.

Keywords: Covid-19, digipedagogical competence, innovation, digitalisation, distance education

$1{ }^{\star}$ Corresponding Author. Faculty of educational sciences, University of Helsinki, Finland; tiina.korhonen@helsinki.fi.

2 Faculty of educational sciences, University of Helsinki, Finland. 


\section{Digitizacija ali digitalizacija: različne prakse v obdobju izobraževanja na daljavo na Finskem}

Tiina Korhonen, Leenu JuUrola, Laura Salo in Johanna Airaksinen

$\propto$ Študija primera preučuje, kako so finski osnovnošolski učitelji organizirali šolske dneve ter kako so učitelji in ravnatelji organizirali virtualno sodelovanje na delovnem mestu in sodelovali s starši v obdobju izobraževanja na daljavo, ki ga je spomladi leta 2020 vsilila kriza, ki jo je povzročil covid-19. Podatki so bili zbrani z intervjuji z osnovnošolskimi in s srednješolskimi učitelji $(n=15)$ iz osmih šol v različnih delih Finske. Izkušnje učiteljev so bile analizirane s kvalitativno analizo vsebine. V tej študiji je šola obravnavana kot kompleksen prilagodljiv sistem, kriza covida-19 pa kot motnja, ki učitelje sili v prilagajanje hitro spreminjajočemu se okolju. Učitelji so tu obravnavani kot inovatorji, ki se $\mathrm{v}$ nenormalnih okoliščinah spopadajo s pedagoškimi in $\mathrm{z}$ digitalnimi izzivi. Na različnih stopnjah digitalizacije v obdobju izobraževanja na daljavo prepoznavamo različne prakse na štirih področjih: 1) sestava šolskih dni; 2) oblike poučevanja; 3) dejavnosti sodelovanja učiteljev in ravnatelja; 4) oblike sodelovanja med domom in šolo. Opredelimo tudi tri skupine spodbujevalcev praks izobraževanja na daljavo: 1) uporaba digitalne tehnologije; 2) digipedagoška usposobljenost učiteljev; 3) sposobnost učiteljev, da delujejo kot prilagodljivi inovatorji. Ugotavljamo, da sposobnost učiteljev za inovacije ter prilagajanje pedagoškega in digipedagoškega strokovnega znanja postajata ključna dejavnika uspeha, ko se izobraževalnemu področju vsiljujejo spremembe. Predlagamo, da se rezultati te študije, prikazani kot dejavniki in področja izobraževanja na daljavo, uporabijo pri načrtovanju izobraževanja v pokovidnem obdobju. V načrtovanje in izvajanje prihodnjih praks v razredih v okviru inovativnih pokovidnih šol je treba vključiti vse deležnike, ki vplivajo na šole na različnih ravneh.

Ključne besede: covid-19, digipedagoške kompetence, inovacija, digitalizacija, izobraževanje na daljavo 


\section{Introduction}

\section{Distance education and education during Covid-19}

The Covid-19 crisis has had a massive effect on schools, students, teachers, and families around the globe. In many countries, the crisis led to school lockdowns, and education transitioned from face-to-face settings to distance learning with little or no preparation time. The impact of these changes will be long-term and continue after the end of the immediate crisis (Schleicher, 2020).

Remote or distance education was already an increasing global trend before Covid-19, strengthening with the development of technology (Mäkelä et al., 2020; Palvia et al., 2018). In industrialised countries, distance education for K-12 students has been applied to solve school crowding challenges, subject availability, and meeting the need for learning at different paces and places (Cavanaugh et al., 2009; Cavanaugh \& Clark, 2007). In Finland, distance education has been used to augment traditional learning environments and has been a topic of educational pilot projects. Online solutions have been used in Finnish primary and secondary education for teaching languages and for teaching students with exceptional circumstances or disabilities (Ilomäki \& Lakkala, 2020; Kotilainen, 2015). Distance teaching solutions were seen to be justified when they solved issues of accessibility, provided more opportunities for learning, such as wider availability of subjects and increased equality in remote areas (Kotilainen, 2015).

In Finland, primary and lower secondary teaching moved to distance education by government decree during the Covid-19 pandemic in the Spring of 2020 for approximately two months (March-May). Teachers had two days to adapt to this change. According to Ahtiainen et al. (2020), most students studied at home throughout the period with no physical contact with the school. In the government distance learning guidelines, $1^{\text {st }}$ to $3^{\text {rd }}$ graders whose parents worked in critical professions were allowed to attend face-to-face teaching, as were students with special needs who could not be taught from home. Thus, teachers worked from either home or school.

Initial surveys in Finland about education and wellbeing during Covid-19 targeting headmasters, teachers, students, school staff, and parents found that practices in solving the challenges of distance education varied among schools and that students adapted differently to the changes. Some students found that they benefited from distance learning, whereas others lacked the prerequisites for distance learning and felt that they learned less than they would have in traditional settings (Ahtiainen et al., 2020; Iivari et al., 2020). 
Variation in distance learning practices was evident in the frequency of online lessons and thus regular interaction with students. Variation also occurred in evaluations. (Ahtiainen et al., 2020; Karvi, 2020). In this situation, the role of support from home and family increased, further widening existing divides. Although less personalised support was available than in a face-to-face setting, teachers innovated new ways for bringing such support to the remote environment. Innovation extended to other communication practices; practitioners found remote conferencing with colleagues and parents to work well (Iivari et al., 2020; Karvi, 2020).

Globally, schools faced similar challenges in taking on distance education, including instructional and pedagogical arrangements, collaborative activities, as well as teacher competence and readiness issues (Schleicher, 2020). Recently published studies address different dimensions of these challenges, and some provide concrete tools and instructional design models for practitioners. For example, Donaldson (2020) identifies the need for supportive networks and describes design principles for digitally enhanced communities of practice (DECop) in this new educational situation. The need for ideating and iterative development is highlighted in a study that offers a pedagogical 'toolkit' for teachers to help respond and adapt to students and class groups' physical and digital needs (Flynn, 2020). Studies also address the challenges of moving hands-on activities to an online form. For example, the use of videos in demonstrating artefacts, improvised teaching, and providing platforms for peer engagement and collaborative learning are seen as potential directions (Jayathirtha et al., 2020).

\section{School as an innovative and complex adaptive system}

The multifaceted nature of the situation for schools in the face of this pandemic is well illustrated by the Complex Adaptive Systems theory (CAS), a complexity theory whereby systems adapt and evolve when faced with change (Mitleton-Kelly, 2003). The theory helps build an understanding of the complexity of the school system and its adaptivity during a disruption (White \& Levin, 2016). According to CAS, systemic activity is based on the interaction between connected actors. The theory looks at unstable states (non-equilibriums) as possibilities for emergent creative solutions and for new ways of working. Change requires a shift into an unstable state. Instability can manifest in various ways, and it may be an ongoing reality for schools, not always resulting in innovation or educational change. Shifts may be caused intentionally with particular aims in mind or unintentionally, as was the case with the Covid-19 
crisis. When disrupted, systems can take up multiple possible solutions. Individuals making decisions in this situation are affected by their history, their current state, and the state of their environment. These decisions can lead to innovation and exploration within the realm of possibilities. Social systems allow for support and choice when disrupted.

In the school context, these change processes can be approached through innovation-driven theories such as the theory of the diffusion of innovations (Rogers, 2003), the theory of educational change (Fullan, 2015), and the Innovative School model (Korhonen \& Lavonen, 2017). The Innovative School model combines the theories of Fullan and Rogers with practical development work of schools aiming at holistic change. The model considers all actors in the school context as participants and innovators: students, teachers, headmasters, parents, and community stakeholders. The interrelationship between actors is complex and occurs across levels (Fullan, 2015). The model is supported by research indicating that participant involvement in innovation implementation and reinvention increases the odds of continued use and development of the innovation. $n$ the model, detailed by Korhonen and Lavonen (2017), collaboration is encouraged on all levels with peer-to-peer learning among students, teamwork between teachers, in home and school collaboration, and in various partnerships. The comprehensive and versatile use of technology in learning and teaching is a guiding and cross-cutting principle in the model. The model shifts the focus to operational innovations, extending innovation from hands-on learning innovations to entire school practices such as school day structures and teacher collaboration.

\section{Teachers as autonomous curriculum implementers and innovators}

In the Finnish educational setting, the teacher is viewed as an autonomous implementer of the curriculum who can make independent decisions regarding teaching methods and tools. Some boundaries are set at the municipal level, but implementations vary widely (Lavonen, 2020). Teachers are also involved in the curriculum development process and are expected to make decisions that align with the curriculum and support students' learning (Halinen \& Järvinen, 2008). During the Covid-19 crisis, Finnish municipalities and schools had, in international comparison, a relatively high autonomy to choose how to react and to organise alternative education (Schleicher, 2020). This autonomy brings with it both freedom and responsibilities. The autonomy and trust given to teachers is a key factor in why the profession is seen as attractive. Challenges of the autonomous teacher include teaching $21^{\text {st }}$-century competencies, meeting 
the needs of diverse students, and mastering changing learning environments and technology (Tirri, 2018).

As the autonomous implementers of the curriculum this exceptional period calls for the ability of teachers to not just adapt to changing circumstances but also use innovation skills to create new practices. Innovation skills are a type of $21^{\text {st }}$-century competence that enables the person to solve real-world problems and innovate with others (Korhonen \& Lavonen, 2017). The individual's contributions to these tasks are considered innovative work behaviour (IWB) (Messmann \& Mulder, 2014; Thurlings et al., 2015). Innovativeness and newness are determined in this study in relation to the users' experiences; specifically, a practice may be known to some but novel to others (Rogers, 2003).

\section{Digitalisation and the digipedagogical competence of teachers}

The need to develop schools' and teachers' digital competences has been present in educational discourse for the past two decades. These developments are driven by the digitalisation of society and an increasing need for teachers to be able to guide students in acquiring $21^{\text {st }}$-century competences, including cross-cutting digital competences. To meet these challenges, the previous Finnish government (2015-2019) launched the concept and goal of a 'digital leap' and invested in the digital competences of teachers and teacher educators. As a result, the concept has been prominent in Finnish public discourse and had a role in putting pressure on teachers and schools (Saari \& Säntti, 2018).

The discourse lacks a definition of digitalisation; often, there is talk about digitisation instead of digitalisation in the educational context. Digitisation is a technical process of moving information into digital form, whereas digitalisation refers to changes in ways of working that utilise digital technology (Tilson et al., 2010). Moreover, public conversations have not brought up the different levels of digitalisation or what is leapt over. Barras $(1986,1990)$ views digitalisation on three levels. On the first level, technology is used to enhance the efficiency of existing services. On the second level, technology is used to improve quality in addition to efficiency. On the third level, technology is used to create completely new or adapted services or ways of acting (Barras, 1986; Barras, 1990). According to Vivitsou (2019), the digitalisation in the educational context can be seen as a metaphorical idea that firstly requires a leap in thinking from the technological to the educational domain and secondly a review of pedagogical methods and changes in educational practices (Vivitsou, 2019).

Various terms have been used to describe teachers' pedagogical use of technology and skills within the realm of digitalisation of education. Such terms 
include ICT skills (Tanhua-Piiroinen et al., 2020), ICT competence (Tanhua-Piiroinen et al., 2020), teachers' digi-skills or competence (Tanhua-Piiroinen et al., 2019, Tanhua-Piiroinen et al., 2020), or TPACK, Technological Pedagogical Content Knowledge (Mishra \& Koehler, 2006). Research results show Finnish teachers' digi-skills vary from weak to expert: based on teachers' evaluation, $10 \%$ of them reported lacking digi-skills, 53\% basic-level skills, 33\% advanced and versatile skills, and 4\% expert-level skills (Tanhua-Piiroinen et al., 2019) with 60\% of teachers having received in-service training in technology (OECD, 2019). A Finnish education survey during Covid-19 found that $95 \%$ of teachers reported that their overall digital skills increased at least a little during distance learning, and $41 \%$ reported a substantial increase (Ahtiainen et al., 2020). Niemi and Kousa (2020) found in their study that even though teachers learned to use technological platforms rapidly, the quality of interaction was lacking.

In this study, we consider the digital skills teachers need in a rapidly changing and digitalised society and propose using the concept of digipedagogical competences. The definition includes the teacher's technological pedagogical content knowledge and the ability to apply this knowledge in different situations (Mishra \& Koehler, 2006). We refer to this set as digipedagogigal skills. The broader concept of digipedagogical competences includes, in addition to the latter, the will (Kopcha, 2012) to use this knowledge and skills to support students' learning, collaboration and interaction. Moreover, digipedagogical competences include using and adapting technology in collaboration with colleagues, parents, and networks. Technology is seen not only as a tool for teaching, learning, interaction and innovation but also as an object of learning (Korhonen \& Lavonen, 2017). Thus, digipedagogical competence also includes the teacher's epistemic knowledge of digitalisation, for example, teacher's knowledge and beliefs (Ertmer et al., 2014) about digitalisation, digital technology, and its benefits to teaching, as well as its societal impact. This affects teachers' attitudes towards digitalisation in education (Korhonen et al., 2021) and their ability to adapt and innovate technology use in pedagogically meaningful ways (Korhonen \& Lavonen, 2017).

\section{Research goals}

The purpose of this study was to explore how Finnish teachers orchestrated school days and how teachers and headmasters organised virtual workplace collaboration and collaborated with parents during the period of distance education forced by the Covid-19 crisis in Spring 2020. We are also interested in the tools and software used, how they were used, and how teachers experienced 
their own digipedagogical and innovation competence. The research questions addressed in this study were as follows:

1. How did teachers organise the school day activities?

2. How did the work community function and support teachers?

3. What was home and school collaboration like?

4. What kind of tools and programmes did teachers use during distance education, and how did they use them?

5. How did teachers describe their digipedagogical and innovation competences?

\section{Method}

\section{Participants}

For this study, 15 teachers with varying teaching experience and teaching various age groups were chosen as interview participants. The teachers work in eight primary and lower secondary schools in Finland. Table 1 lists the study participants with their background data. In selecting the participants, we utilised a national school innovation network and its regional coordination areas. Teachers were chosen from eight coordination municipalities representing various regions from all parts of the country and different size schools. Teachers with and without special roles were chosen for the study.

In Finnish basic education, most teachers work as either class teachers in primary school, teaching $1^{\text {st }}$ to $6^{\text {th }}$ grade (ages $7-12$ ), or as subject teachers in lower secondary school teaching $7^{\text {th }}$ to $9^{\text {th }}$ grades (ages 13-15). Each class in lower secondary school also has a teacher designated the class supervisor. In addition, there are also special education teachers focused on special education classes or supporting the individual needs of students of the whole school in both primary and lower secondary levels.

\section{Table 1}

Study participants: subject indicates if the participant teaches a class of a specific subject; special roles refer to teacher's secondary duties, if any

\begin{tabular}{cccclccc}
\hline ID & Subject & Grade & Students & School size and area & Region & $\begin{array}{c}\text { Experience } \\
\text { (years) }\end{array}$ & Special roles \\
\hline 1 & Class & $1^{\text {st }}$ & 6 & Medium Urban & Western & 11 & Tutor teacher \\
2 & Class & $1^{\text {st }}$ & 23 & Medium Urban & Eastern & 4 & ICT responsible \\
3 & Class & $2^{\text {nd }}$ & 17 & Small Rural & Eastern & 5 & - \\
\hline
\end{tabular}




\begin{tabular}{|c|c|c|c|c|c|c|c|}
\hline ID & Subject & Grade & Students & School size and area & Region & $\begin{array}{l}\text { Experience } \\
\text { (years) }\end{array}$ & Special roles \\
\hline 4 & Class & $2^{\text {nd }}$ & 20 & Medium Urban & Eastern & 10 & - \\
\hline 5 & Class & $3^{\text {rd }}$ & 18 & Large Urban & Central & 18 & - \\
\hline 6 & Class & $3^{\text {rd }}$ & 18 & Large Urban & $\begin{array}{l}\text { North- } \\
\text { ern }\end{array}$ & 25 & - \\
\hline 7 & Class & $3^{\text {rd }}$ & 20 & Large Urban & $\begin{array}{l}\text { North- } \\
\text { ern }\end{array}$ & 32 & - \\
\hline 8 & Class & $4^{\text {th }}$ & 16 & Large Urban & Capital & 1 & Digi-tutor \\
\hline 9 & Class & $4^{\text {th }}$ & $32^{*}$ & Small Urban & Capital & 29 & $\begin{array}{l}\text { Vice headmaster, } \\
\text { tutor teacher }\end{array}$ \\
\hline 10 & Class & $5^{\text {th }}$ & 16 & Small Rural & Western & $25-30$ & $\begin{array}{l}\text { Vice headmaster } \\
\text { digipedagocical } \\
\text { trainer }\end{array}$ \\
\hline 11 & Class & $6^{\text {th }}$ & 27 & Large Urban & Central & 9 & - \\
\hline 12 & Class & $6^{\text {th }}$ & 18 & Small Rural & Eastern & 25 & Headmaster \\
\hline 13 & Class & $6^{\text {th }}$ & 9 & Small Rural & Western & 20 & Tutor teacher \\
\hline 14 & Crafts & $7-9^{\text {th }}$ & $7 \times 18^{* *}$ & Large Urban & Eastern & 8 & - \\
\hline 15 & STEM & $7-9^{\text {th }}$ & $\begin{array}{c}10 \times \\
20^{* * *}\end{array}$ & Medium Urban & Western & 13 & - \\
\hline
\end{tabular}

Note. *Team teaching group; **7 groups, 18 per group; ${ }^{* * *} 10$ groups, 20 per group.

\section{Data collection and analysis}

The data acquisition method was semi-structured interviews conducted during Spring 2020 between the $18^{\text {th }}$ of May and the $4^{\text {th }}$ of June 2020 , when schools had just returned to face-to-face teaching after a two-month distance education period. The interviews lasted from 54 minutes to 1 hour 48 minutes and were conducted on online platforms by four researchers. Participating teachers were interviewed about how they organised their distance school days, collaborated with the work community and parents, utilised technology, and developed digipedagogical expertise.

This study takes a qualitative approach in describing and understanding the impact of the Covid-19 crisis on the individual teacher within the context of their school and working community. The data were analysed by inductive content analysis, as there was an interest in examining teachers' novel distance education practices as they came to light in their interviews (Elo \& Kyngäs, 2008). The unit of analysis was defined as a single coherent idea (Saldana, 2016); in the analysis, the number of mentions $(n)$ is presented. Each mention can belong simultaneously to one or more categories as it can contain different perspectives. Initial analysis categories were derived from the interview questions, after which 
the data was reviewed multiple times across investigative cycles to construct the main categories and subcategories. To improve the reliability of our analysis, the first and second authors refined the categorisation framework by testing and retesting in relation to the data excerpts. Finally, units were coded based on the categorisation framework as domains and enablers of distance education.

\section{Results}

\section{Practices during distance education (research questions 1, 2 and 3 )}

We identify types of practices within four domains: 1) structure of school days, 2) forms of teaching, 3) collaborative activities of teachers and headmaster, and 4 ) forms of home and school collaboration (Table 2).

\section{Table 2}

The identified domain and their practices, with the number of mentions $n$ for each practice and an example of a mention of the practice (translated from the original Finnish)

\begin{tabular}{|c|c|c|c|}
\hline Domain & Type of practice & $\mathrm{n}$ & Example of mention \\
\hline \multirow{3}{*}{$\begin{array}{l}\text { Structure of } \\
\text { school days }\end{array}$} & Schedule & 92 & $\begin{array}{l}\text { We had } 45-\text { minute classes and then a break and lunch } \\
\text { break was half an hour, so that was like a very routine } \\
\text { daily schedule. }\end{array}$ \\
\hline & Meetings & 38 & $\begin{array}{l}\text { I always had the first meeting quarter past eight in the } \\
\text { morning, which became like a routine. }\end{array}$ \\
\hline & Breaks & 12 & $\begin{array}{l}\text { Not a 15-min break after each class, but we were looking } \\
\text { at fitting small breaks into gaps }\end{array}$ \\
\hline \multirow{5}{*}{$\begin{array}{l}\text { Forms of } \\
\text { teaching }\end{array}$} & $\begin{array}{l}\text { Teacher-led } \\
\text { teaching }\end{array}$ & 158 & $\begin{array}{l}\text { Of course, there was quite a bit of that old-fashioned } \\
\text { teaching in the beginning, where the teacher says how } \\
\text { things are and what we do. }\end{array}$ \\
\hline & $\begin{array}{l}\text { Independent } \\
\text { work }\end{array}$ & 149 & $\begin{array}{l}\text { The ideas in arts and crafts were such that they could be } \\
\text { done at home at their own pace, and you got the idea } \\
\text { readily from the instructions. }\end{array}$ \\
\hline & $\begin{array}{l}\text { Individual guid- } \\
\text { ance }\end{array}$ & 114 & $\begin{array}{l}\text { I had specific supporting teaching after school days, and } \\
\text { we agreed that certain students would join me online } \\
\text { at the end of the day, and we'll then get back to things } \\
\text { together in more detail. }\end{array}$ \\
\hline & Evaluation & 84 & $\begin{array}{l}\text { During this distance schooling period, we also did have } \\
\text { exams, and I got the submissions by email or somebody } \\
\text { even submitted by WhatsApp. }\end{array}$ \\
\hline & Group work & 31 & $\begin{array}{l}\text { We had in Teams a team for each school subject, and I } \\
\text { created groups in each team; I changed the roster around } \\
\text { in different subjects a bit and sometimes said that I } \\
\text { would set up new channels per group so that you could } \\
\text { decide on the groups yourself. }\end{array}$ \\
\hline
\end{tabular}




\begin{tabular}{|c|c|c|c|}
\hline Domain & Type of practice & $\mathrm{n}$ & Example of mention \\
\hline \multirow{2}{*}{$\begin{array}{l}\text { Collaborative } \\
\text { activities of } \\
\text { teachers and } \\
\text { headmaster }\end{array}$} & Peer-support & 219 & $\begin{array}{l}\text { [Collaboration] was certainly very important; we worked } \\
\text { out many technical issues and also just practical things } \\
\text { and what we're going to do during the week and how we } \\
\text { progress with students. }\end{array}$ \\
\hline & Leadership & 143 & $\begin{array}{l}\text { Our headmaster has really put their neck and effort into } \\
\text { this and did a lot of work to make teaching succeed dur- } \\
\text { ing the distance ed period and also after that as we got } \\
\text { back to normal school. }\end{array}$ \\
\hline \multirow{3}{*}{$\begin{array}{l}\text { Forms of } \\
\text { home and } \\
\text { school col- } \\
\text { laboration }\end{array}$} & Communication & 84 & $\begin{array}{l}\text { I always notified of important things in Wilma. Parents } \\
\text { read Wilma and I told the kids the site where I run teach- } \\
\text { ing. After a couple of rounds, everybody found their way } \\
\text { to the site at } 8 \text { or } 9 \text { in the morning. }\end{array}$ \\
\hline & $\begin{array}{l}\text { Support for } \\
\text { students }\end{array}$ & 60 & $\begin{array}{l}\text { We put Meetti (Google Meet) into use very quickly; I } \\
\text { had like a permanent link that students knew well, and } \\
\text { parents of course helped, so it would not have come to } \\
\text { that without parents helping at home. }\end{array}$ \\
\hline & $\begin{array}{l}\text { Support for } \\
\text { parents }\end{array}$ & 23 & $\begin{array}{l}\text { There were also families where parents could not really use } \\
\text { these either so we for sure had long support calls and also } \\
\text { called home like how you should start up these gadgets. }\end{array}$ \\
\hline
\end{tabular}

\section{Structure of school days}

Schedule. Teachers described the sudden pressure to rapidly build a whole new daily school routine. They emphasised pedagogical sensibleness in their practices: accounting for students' age group, meaningfulness, and support for students' individual progress. Some teachers strove to shape school days to be as similar as possible to in-school teaching, while others immediately considered the possibility of restructuring for distance teaching and the capabilities of distance working.

There were considerations about teachers' digipedagogical competence, their ability to apply their skills in a new situation, and their circumstances at home as their spouse and children were also working and studying from home. The devices, programmes and services available played a significant role in schedule planning. Equally significant was the teachers' ability to plan the use of these tools in a meaningful way for both independent and joint work. Moreover, guidelines and conditions set by the headmaster or the municipality influenced the schedules.

Several class teachers described shortening school days. Teachers justified this with references to student wellbeing and the opportunity to add time for individual guidance to the end of group teaching. Subject teachers in secondary school also relaxed the schedule as students were allowed to work relatively independently.

Teachers reported challenges in planning their workdays. For example, if schedules were not clearly communicated to students and parents or not 
internalised by the teacher, the latter risked stretching their work hours. In addition, due to some students being allowed to attend face-to-face teaching at school, some teachers were required to adapt their schedule to teach both their own class online and another class in a face-to-face setting, taking turns in faceto-face classes with colleagues.

Meetings and breaks. All interviewed primary school teachers organised a joint morning meeting similar to face-to-face school where students reviewed their previous day and teachers introduced the day's schedule and tasks. Teachers also often used this session to teach one of the day's topics. The rest of a student's school day alternated between independent work, breaks, and possibly joint sessions where the teacher either went through students' tasks or taught new lessons. Secondary school teachers describe the school day as consisting of joint meetings and tasks disseminated to students. The schedule was constructed from possible morning meetings with the class supervisor and tasks set by various subject teachers.

Teachers also noted the importance of taking breaks, which are especially evident in primary school distance teaching, where there were often longer teacher-led sessions. Some teachers scheduled breaks similarly to face-to-face school days with 45-minute lessons followed by a 15-minute break. Other teachers had a different rhythm with both longer teaching sessions and longer breaks.

\section{Forms of teaching}

Teacher-led teaching. Teacher-led teaching included the above-described morning meetings, possibly with teaching sessions and any other teacher-led activity. When discussing the different subjects taught, teachers often started with mathematics teaching. They found it natural to follow the normal mathematics lesson structure in distance learning with first checking homework and then learning a new topic. Ready-made digital mathematics learning materials from commercial publishers worked well when shared via the teacher's screen. In addition, some teachers gave students reflection tasks, after which students were allowed to leave the joint session and work independently or stay in the meeting and get help from the teacher.

Independent work. Teachers reported giving much thought to the suitable length of teaching sessions for each age group. They pondered the balance of joint and independent activities and observed that working and learning from home requires a new form of self-responsibility and self-discipline. Especially among $1^{\text {st }}$ - and $2^{\text {nd }}$-grade teachers, there were reports of shortening the length of teacher-led work based on their observations. Some teachers guided students 
to work independently with daily or weekly guidelines or in both ways, giving daily guidelines for some subjects and weekly tasks in other themes.

The role of independent work was especially emphasised in arts and crafts. Both classroom teachers and subject teachers described guiding students in arts and crafts solely towards independent work. teachers utilised many ready-made online materials and, for instance, in handcrafts, tasked students with assignments related to housekeeping themes.

Directions for independent tasks were often found on a platform available to students, where the teacher had also included homework and possible additional materials. The same directions were usually communicated to parents via Wilma, a web interface used for home and school collaboration. A secondary school teacher described varying ways to instruct weekly assignments: some teachers gave students separate instructions for every subject, whereas some teachers decided to create a shared document where each subject teacher marked the following week's tasks on a weekly basis. This arrangement made it easier for students to follow the guidelines of many teachers.

Individual guidance. Teachers often brought up individual guidance to students and its importance. The primary function of individual guidance in distance teaching was reaching students and noticing students' individual needs. At the beginning of the day, both class and subject teachers checked that students were present. If there was an uninformed absence, teachers attempted to reach the student in various ways. In these situations, special education teachers were of assistance in some schools.

Teachers described several ways of giving individual guidance, such as remedial instruction similarly to face-to-face settings or staying behind at the end of the online joint lessons. Another form of individual guidance that required self-directed action was the possibility to call the teacher at a specified time. Individual guidance was also given at the teacher's initiative. If a teacher noticed a student in need of support, they were in personal contact with the student and provided that guidance. Some teachers reported making a weekly round of calls to students asking how they were doing and learning about possible needs for support.

Evaluation. During distance education, ongoing evaluation through checking assignments and giving both oral and written feedback was highlighted. In addition to ongoing evaluation, a few teachers mentioned that they gave tests or exams to students. In one class, a teacher mentioned using an online evaluation platform.

Group work. Teachers described challenges in organising group work during distance education. Implementation challenges were mostly comprised of teachers' lack of digipedagogical competence, which meant that teachers 
could not adapt the used platforms for group work and divide students into groups. Moreover, most platforms used at schools during Spring 2020 did not yet have these group features. Despite this, some teachers were successful in guiding students in pair or group work. The absence of group tools was solved in many ways: by directing students to call their partner on the platform and work together, creating an open and recurring meeting link for students to join anytime, or setting up each group with their own channel on the platform.

\section{Collaborative activities of teachers and headmaster}

Peer support. Teachers described diverse ways of collaboration and the peer support received in planning teaching, creating learning materials, and putting teaching into practice. Teaching was planned, and materials were created in age- and subject-level teacher groups. Other group formations were primary and secondary school teacher groups that could include a special education teacher. The groups were existing teacher teams such as a digi-team, or groups that formed spontaneously or were put together by the headmaster. Teachers collaborated either in distance form or in face-to-face settings at school.

Teachers reported that support from other teachers helped them cope in an uncertain and completely new situation. Informal or formal messages and discussions led by the headmaster or colleagues helped teachers solve problems relating to organising and implementing distance education. Peer support in issues involving digital technology was often evident in teachers' speech. Sharing the workload and responsibilities was also mentioned. For instance, some of the primary school teachers in the same grade level observed that it is beneficial to divide planning responsibilities for teaching among teachers. Other teachers, in contrast, described situations in which some teachers were unwilling to collaborate or receive help from others.

Leadership. School leadership was brought up from the point of view of clarity, accessibility, and safety. In some schools, the school headmaster and vice headmaster reacted to the situation quickly, delivering clear guidelines to teachers on the headmasters' role in disseminating general guidelines as well as on how to implement distance teaching and communicate with parents. In other schools, teachers felt that the directions given by the school were confusing: directions were given from both the school management and from the municipality separately, and the teacher lacked adequate guidance on platforms that were available for use in distance education. In addition, teachers felt that this dual-level guideline and changes in directions during the distance education period were stressful. The criticism was especially targeted at the municipality level. 
Varying ways of leadership were evident also in the accessibility of headmasters. Some teachers mentioned always getting answers to their questions, while others stated that they did not receive enough support from management. The feeling of safety is also mentioned with regard to headmaster accessibility and the nature of given directions. The headmasters' encouraging, sturdy and positive grip on the situation made teachers feel that the situation was under control. The customs for joint meetings led by headmasters varied from school to school, from headmaster-led announcement meetings where the teachers were merely listeners to meeting customs where headmasters arranged the possibility for questions and structured participation.

\section{Forms of home and school collaboration}

Communication. The accessibility of teachers, students, and parents was a key factor in home and school collaboration. Some of the $1^{\text {st }}$ and $2^{\text {nd }}$-grade students were hard to reach due to the lack of practice in using online platforms. Similar challenges were apparent in some higher grade levels. Teachers also had to consider which of the platforms were available to students and which to parents. Parts of the platforms used were intended only for parents (e.g., the Wilma home-school collaboration platform) and some only for students (e.g., Teams). Some of the teachers reported that, at times, parents were also hard to reach. Some families did not want to use digital technology as a matter of principle. Teachers showed understanding of the families' demanding circumstances and matters of principles. Teachers took up a 'mentoring' role in supporting families in adopting the necessary technology or finding alternative communication forms in distance education.

The accessibility of teachers also had a significant role in home and school collaboration. Some teachers described clearly setting boundaries to the time when they were available. Some teachers, in turn, depicted being at their students' disposal at all times. Teacher communication to parents happened on a daily basis, a couple of times a week or once a week. Some teachers reported taking up individual phone calls with all parents at least once during distance education.

Support for students. Students received support in distance education from both teachers and parents. Teachers describe students receiving support from parents in both organising the school day and the study topics. Teachers were grateful to parents for supporting students in this new and abrupt situation and guiding them into a new way of going to school. Some teachers reported that they wanted to avoid putting pressure on parents to guide their children 
in distance learning, because they were aware that in most homes, parents and siblings also worked from home. A portion of teachers adapted their instructions for tasks in consideration of these circumstances.

Some teachers expressed the challenges of some students in distinguishing being at home from distance schoolwork and in understanding the time used for schoolwork in distance learning as compared to normal school. Some of the older secondary school students had not comprehended the time usually spent on school and homework. Students felt that the time allocated for assignments was too long even though they had used only a fraction of the time on it compared to normal school days. In these situations, the importance of teacher and parent guidance increased. Support from the special education teacher was also utilised in many ways. In one school, the special education teachers worked with the individual students who had challenges in participating in distance education when in other schools they worked to support special education classes.

Support for parents. Teachers supported parents during distance education by messaging them via various channels about how teaching was carried out and by directing them in guiding the student at home. Teachers' support for parents in adopting technology was often mentioned when describing homeschool collaboration. Some teachers reported guiding parents by hand, so they could get programmes and services to work at home.

The teachers' descriptions of collaboration with parents during distance education reflected, for the main part, a sense of a common goal. A mutual desire to organise school activities in an otherwise uncertain and chaotic time was depicted clearly in teachers' reports. The willingness to support parents and hear their thoughts was also telling in the messages and phone calls to homes. One teacher reported doing a survey for parents at the beginning of distance education to get the widest possible perspective on the situations at home to consider in their work. Similar surveys were given in some schools to all parents.

\section{Enablers of distance education practices (research questions 4 and 5)}

We identified three groups of enablers that cut across and affect all the four domains of distance education practices: 1) the use of digital technology, 2) the digipedagogical competence of teachers, and 3) teachers' ability to act as adaptive innovators (Table 3 ). 
Table 3

The identified enablers and enabled groups, with number of mentions $n$ for each enabled group and an example of a mention of the enabler (translated from original Finnish)

\begin{tabular}{|c|c|c|c|}
\hline Group & Enabler & $\mathrm{n}$ & Example of mention \\
\hline \multirow[t]{2}{*}{$\begin{array}{l}\text { Use of digital } \\
\text { technology }\end{array}$} & $\begin{array}{l}\text { Tools and } \\
\text { services }\end{array}$ & 377 & $\begin{array}{l}\text { In Teams we certainly used the features we } \\
\text { have there, we have there tasks and question- } \\
\text { naires and I event started 'youtubing' like my } \\
\text { students say, as I sometimes did YouTube } \\
\text { videos for crafts. }\end{array}$ \\
\hline & Usability & 228 & $\begin{array}{l}\text { Submissions were for the most part in picture } \\
\text { format because it was easier for them. }\end{array}$ \\
\hline \multirow{2}{*}{$\begin{array}{l}\text { Digipedagogical } \\
\text { competence of } \\
\text { teachers }\end{array}$} & $\begin{array}{l}\text { Digipedagogical } \\
\text { skills }\end{array}$ & 187 & $\begin{array}{l}\text { I guess overall our teacher cadre is pretty good } \\
\text { at using those. I am not, like, specially good } \\
\text { compared to colleagues, but I would say I have } \\
\text { pretty good skills. }\end{array}$ \\
\hline & Attitude & 139 & $\begin{array}{l}\text { After the initial shock, we got it running really } \\
\text { well, and I started actually enjoying it and } \\
\text { noticed that distance learning improved, and I } \\
\text { would not have liked to stop as I got it working } \\
\text { so incredibly well, very good vibes. }\end{array}$ \\
\hline \multirow[b]{2}{*}{$\begin{array}{l}\text { Teachers as adaptive } \\
\text { innovators }\end{array}$} & $\begin{array}{l}\text { Problem solving } \\
\text { and creativity }\end{array}$ & 112 & $\begin{array}{l}\text { That I could create tasks in crafts that they } \\
\text { could do at home. }\end{array}$ \\
\hline & Co-creation & 73 & $\begin{array}{l}\text { We saw each other like each morning, so it } \\
\text { was a bit like part of normal, work day, and } \\
\text { then we exchanged ideas and figured out how } \\
\text { to do things. }\end{array}$ \\
\hline
\end{tabular}

\section{Use of digital technology}

Tools and services. The sudden transition to distance learning brought to light a real inequality in terms of equipment availability. Some of the teachers were issued phones and laptops; for some, neither were provided by their employer. Equipment availability also varied for the students, with some having access to both a laptop and a tablet through their school while some students were left without access to a computer. Schools borrowed equipment for homes that could not arrange one for the student. Homes with multiple students faced an especially challenging situation, forcing the students to take turns with the equipment. Some students relied solely on their smartphones.

The devices, software, and services had a major impact on the structure of the school day, as well as on teaching and home-school collaboration practices. Teachers described communicating in a plethora of ways, including messaging (calls, chat, text messages, Wilma, WhatsApp) and online meeting platforms (Teams, Pedanet, Google Classroom and others). In their teaching, 
the teachers utilised various cloud services, ready-made videos, or videos they recorded themselves, learning features of online meeting platforms and readymade online learning materials from commercial publishers. They started their day in a video call (Teams, Google Hangout, Meet) and delivered daily/weekly learning tasks to students through online platform folders or in chat messages. They ran teaching sessions on a video conferencing platform, sharing their selfmade or commercial learning material on their screen. Many sessions, such as those for checking student status, were plain video conferences. Some teachers describe their efforts to engage students using the free versions of the Padlet and Kahoot services and to arrange exams using the Socrative tool.

Teachers created their video learning material using, for example, the free versions of screen recording software. They created video content to remedy the lack of textbooks or other learning material and allow students to review their teaching later. Some teachers mentioned discovering the usefulness of self-made videos for students' learning and their intention to continue the practice.

Teachers described inventing their own mechanism for submitting assignments, which was necessary when they did not have access to online platforms or did not have the skills to use one. $1^{\text {st }}$ - and $2^{\text {nd }}$-grade teachers and other lower primary school teachers made extensive use of WhatsApp, both in communication and as a tool for submitting pictures of assignments. Using WhatsApp brought out various questions about online privacy and user age limits. Some teachers were aware that these limits would prohibit the use of certain services but still used them, justifying the use by the acute situation. Other teachers did not possess information about the allowed/disallowed services. Some parents explicitly prohibited their children from using certain services on the basis of age limits or privacy.

The teachers also utilised the same software and services for collaboration with their colleagues. Weekly faculty meetings were arranged as videoconferences, and the primary communication channel between teachers was instant messaging.

Usability. Teachers mentioned usability considerations related to network connectivity, software and service user experience, and service access. They mentioned both positive and negative experiences. Working devices, software, and services received praise, with teachers who had their first exposure to their use describing their enthusiasm stemming from their positive user experience. Typical usability challenges included network issues (dropped connections or slowness) and various error cases in software and services. One teacher in a school using multiple online platforms described the overwhelming array 
of services and their confusing use. They felt that selecting a primary platform would be important.

\section{Digi-pedagogical competence of teachers}

Digipedagogical skills. The distance learning period made teachers think about their own and their colleagues' digipedagogical skills. They described teachers who could not tell the difference between local files on a computer and files shared on a cloud service and teachers who had never been on a video call. In contrast, some of the teachers acted as digital tutors in their school or as trainers in regional or national networks and have wide-ranging expertise in both the device, software, and service technology and their pedagogical application. Teachers thought about the reasons for this skill gap (e.g., teachers' unwillingness to get trained on or self-learn the use of digital technology in teaching and collaboration). One teacher reasoned that their skill gap came from teaching Grades 1-2 for several years and thus not being exposed to advanced tools.

Differences in teachers' skills affected their pedagogical choices. Some used technology only for communication, placing their students primarily in self-study mode at home. Other teachers who were more skilled with technology made flexible and extensive use of it, allowing their students to benefit from other learning modes involving joint and group sessions.

On the one hand, teachers with weaker digipedagogical skills described their insecurity in arranging remote teaching. They would have needed more detailed guidance in selecting and using devices and software. Teachers mentioned spending a great deal of time attempting to copy their face-to-face teaching practices to a remote setting without realising that the tools afford simpler ways to achieve the same goals. On the other hand, several teachers said that the forced situation activated their willingness to adopt new digital methods. Some teachers with weaker skills realised that the technology is not so hard, motivating them to further use.

Teachers pondered the roles related to digipedagogical skills development in their school and the visibility of the current skill level. In some schools, the responsibility for advancing these skills was with a special digital teaching advocacy role (ICT-responsible or digi-tutor); in other schools, several teachers contributed to skills development. They also described teachers who actively avoided digital technology and learning the related skills. According to the teachers, the distance-learning period brought out skilled teachers who could have normally been overshadowed by the more skilled special advocates. 
Teachers also spoke about their need for personalised training; they longed for focused training that would start from their needs and personal support in developing their digipedagocical skills. They also mentioned the lack of time and lack of a learning community in their school. Some teachers called for the definition of a basic digipedagogical skill level that all Finnish teachers should reach.

Attitude. According to teachers, key factors influencing the development of digipedagogical competence were fears, prejudices, and attitudes toward technology, the use of digital technology and the development of related skills. Some teachers feared learning about digital technology because they felt that they had inadequate skills. They may have passed over training opportunities for a long time and felt that the fast pace of technological development built up an insurmountable learning challenge.

Attitudes toward the use of digital technology ranged from highly positive to negative. Some teachers described a change in their attitude during the distance learning period. After they were initially forced to use the technology, they reviewed their thinking and found some of their preconceived notions false. Skill development that was earlier seen as an activity controlled and demanded from the outside now became a pressing, internal, and personal need to get skilled to cope with the sudden situation. When discussing the forced situation, teachers mentioned an increased sense of community and a wish that all their colleagues would have assumed a more positive attitude towards skills development. They also called for courage to try without fear of failure and for the involvement of students in advancing teachers' digipedagogical skills.

\section{Teachers as adaptive innovators}

Problem solving and creativity. Teachers said that, especially at the start of the distance learning period, they were constantly creating new practices for teaching and collaboration with colleagues and homes to address previously unforeseen problems. They felt that problem-solving skills and creativity were key in setting up working practices. Teachers described innovations in teaching arrangements, including teaching methods, teaching content, and learning materials.

Teachers realised that letting go of familiar practices and innovating new ways was the only available course of action. As a result, some teachers previously stuck in their ways learned to enjoy solving challenges and rediscovered their passion for their work. Teachers also realised that the work and new tools during the period have supported both them and their students in practising their logical reasoning and innovative problem-solving skills. 
Co-creation. Collaborative brainstorming, sharing, and benchmarking ideas helped teachers find distance learning practices that worked for them and their students. Several teachers shared responsibility for designing and implementing distance learning with their colleagues. This activity guided them towards collaborative ideation. Some teachers felt that tighter collaboration became a necessity and that traditional obstacles for collaboration were overcome. Several teachers described how they shared digipedagogical skills and innovated together on the use and the challenges of devices, software, and services. Their collaboration grew in steps or started in full force right away. Some teachers also described situations in which some of their colleagues were not ready to collaborate or participate in collaborative ideation.

The experience of taking part in close collaboration and receiving peer support during the distance learning period prompted teachers to think about the ongoing role of collaboration in their work. They had participated in collaboration before the period but felt that they had found new ways to engage in deeper collaboration, ideation, and sharing of responsibility.

\section{Discussion}

The results described practices in use during the distance learning period as well as enablers that made deployment of the practices possible.

\section{Distance learning practices}

According to the results, teachers built their school day structure in various ways by combining online meetings and breaks. Some teachers strived to have the distance school day resemble normal face-to-face school days and planned accordingly. However, other teachers planned and implemented teaching with considerations of the new situation and possibilities of distance teaching. The results show that students' age, available tools and programmes, teachers' digipedagogical competence, and the circumstances of homes influenced the planning of structure and the implementation of school days.

Forms of teaching varied from teacher-led sessions to independent work. Finding a suitable rhythm and balance was especially challenging for teachers at the beginning of distance education. Teacher-led work included morning meetings with the whole class, teaching various subjects, going through guidelines, and catching up with students. The role of independent work was emphasised. The challenges of organising and implementing pair and group work were similar to those in other countries (Schleicher, 2020). The challenges of 
collaborative work were dependent on teacher and student skills and the available platforms.

The first published results from the Covid-19 distance learning period in Finland hint at insufficient and unequal personalised guidance (Ahtiainen \& al., 2020; Karvi, 2020). However, the results of this study show individual guidance as one of the key considerations for teachers as they planned and implemented distance learning. Teachers were foremost concerned with students' accessibility and with their own ability to notice needs for support. Individual guidance was available at the initiative of either the teacher or the student.

Earlier studies emphasise the collaboration between teachers, clear collaborative structures, and leadership in coping with new situations (Donaldson, 2020). These conclusions are supported by the results of the current study on the collaboration between teachers and headmasters. Teachers supported each other in both planning and implementing teaching. The collaboration took place either in existing groups or in groups that formed spontaneously during distance education. However, some teachers did not take part in collaboration. Teachers' feelings of safety and trust in their work amid a chaotic state could be achieved by clear guidelines and the encouragement and accessibility of headmasters. Uncoordinated, unclear, and inaccessible leadership was an issue that added to teachers' insecurities and hampered their work.

The results of this study on home-school collaboration generally affirm earlier results (Karvi, 2020) regarding the impact of the parents' role but also highlight teachers' willingness to support parents and students with distance learning practices and tools. Teachers supported parents by striving to communicate clearly about timetables, ways of working, and tasks. Teachers also provided personal support to some parents in adopting tools and programs used in distance education. Both teachers and parents guided and supported students in adopting new ways of going to school, doing assignments and taking up digital technologies.

\section{Distance learning enablers}

Teachers made use of digital technology both in their teaching and in their collaboration with students, parents, and colleagues. Online meeting and learning platforms available at municipalities and schools, self-made or publisher materials, and especially official and informal instant message platforms were utilised in teaching and interaction. Concerns about data security and age limits were brought up. There were also discussions regarding the rules, directions, and usability of tools and programs. The shift to distance education brought out issues 
regarding equality in digital equipment availability identified in earlier studies (Ahtiainen et al., 2020; Karvi, 2020; Tanhua-Piiroinen, 2019).

Our research results confirm findings from previous Finnish studies on teachers' competences (Tanhua-Piiroinen, 2019). In our results, teachers' digipedagogical competences vary from weak to expert-level. The weak competences may be due to some teachers still having negative attitudes toward digipedagogical professional development. In contrast, the forced distance learning period has made teachers aware of the digipedagogical competence level of other teachers and led them to appreciate the importance of digipedagogical competences and reconsider their prejudices. The forced pedagogical trials made during this period assured teachers of their ability to learn and utilise technology to support teaching and learning quickly. Such a crisis situation calls for teachers' responsibility in learning digipedagogical competences, as Tirri (2018) points out when emphasising the demands for autonomous teacher's ability for continuous learning and reflection on professional attitudes.

The distance education period brought out not just the digipedagogical skills and attitude related to technology use but also teachers' ability to act as innovators. In the Finnish context, this ability is especially made possible by the pedagogical autonomy of teachers (Tirri, 2018). The mere availability of digital tools and programs and the presence of digital and pedagogical skills (Mishra \& Koehler, 2006; Tanhua-Piiroinen, 2019, 2020) is not enough to foster innovation. In these results, teachers exhibited creativity, problem-solving skills and innovative work behaviour (Fullan 2015; Messmann \& Mulder, 2014; Rogers, 2003) when facing challenges in organising distance education. This also relates to Vivitsous' (2019) discussion on hybrid education and digitalisation in the educational context, where it is noteworthy that teachers had to be able to 'in situ' adapt and innovate their virtual and face-to-face classroom practices in the ongoing situation in real time (Vivitsou, 2019). Through creating new ways of working and using technology, some teachers report getting excited about their work again. Some report enjoying solving the arising challenges. The co-development, ideating, and planning of teaching among teachers emphasised by Flynn (2020) plays a significant role here. The results point that the continued use of ideas and co-development models created during distance education may also be important in further school development after the distance education period.

As a summary of the case study results, it can be said that by adopting the holistic view from the Innovative School model of all school actors, including teachers, students, headmasters, and parents (Korhonen \& Lavonen, 2017), we find that all of these actors played a role in the adaptation of the school's complex system to a forced externally imposed change. Teacher-made 
decisions aligned with CAS-theory (Mitleton-Kelly, 2003; White \& Levin, 2016), being based on teachers' own history and circumstances in interaction with headmasters, students, and parents. The decisions led to diverse practices in teaching and collaborating in different areas in Finland, also influenced by available tools and programs and their usability, teachers' digipedagogical competences, and teachers' individual and collaborative innovating skills.

\section{Conclusion}

Early published reports and studies on the Finnish Covid-19 distance learning period primarily describe the effects of distance education on schoolwork, teaching and wellbeing, as well as providing themes for best practices. This study adds a teacher-centred view to the discussion by giving an in-depth and diverse description of everyday practices and enablers. The study also highlights the multifaceted role of digipedagogical and innovation competences in the changing educational context.

Finnish teachers were able to cope with the Covid-19 situation by drawing upon both their high-level pedagogical skills and ability to create innovative solutions new to their practice using available devices, software, services, and materials. The teachers were also willing to guide and support both students and parents during this exceptional period. Teachers with weaker digipedagogical skills were forced to fill in skill gaps through self-study and peer support.

In light of the levels of digitalisation defined by Barras $(1986,1990)$ and considering the definition of digitalisation by Tilson et al. (2010), we can say that teachers were primarily digitising existing face-to-face teaching, acting on the first level of digitalisation with their efforts to re-implement school in a distance education setting. Following Vivitsous' (2019) discussion on hybrid learning environments, reaching 'spaces where different voices speak in a coherent manner in order to work jointly for shared solutions' (p. 126) has yet to be accomplished. This is reasonable given the need for sudden change and socio-emotional strain because of the pandemic; nevertheless, some teachers took a different approach and designed new practices based on the new possibilities offered by digital technology. In doing so, they were trying from the start to digitalise school practices, working on higher levels of pedagogically meaningful digitalisation.

To allow more teachers to continue the pedagogically meaningful utilisation of digitalisation of school practices in preparation for post-Covid education and draw on the inherent motivation to do so arising from their Covid-19 experience, more teachers must acquire better digipedagogical competences 
(i.e., competences that link together technological prowess with the ability to apply and innovate in the now blended school context). We recommend that the results of this study portrayed as the practices and enablers of distance education would be utilised when planning for post-Covid education. All stakeholders involved in school development should be included in envisioning and implementing future classroom practices of innovative post-Covid-19 schools (Korhonen \& Lavonen, 2017). The autonomous role of Finnish teachers made innovation possible in these circumstances; however, not all teachers could meet these requirements. Future plans need to consider how to support schools and teachers in changing realities so that teachers with different competence levels working in different educational cultures can implement quality classroom learning and interaction practices. In practice, digitalisation work will need school organisations that foster collaborative development (Donaldson, 2020; Flynn, 2020) and teachers with a positive attitude towards and personal responsibility for their skill development. Thurlings et al. (2015) point out that the teachers' possibility to innovate, utilise new solutions in their work and share these practices with other teachers depend on, in addition to individual and organisational factors also on external factors like curricula and policies. Curriculum and educational policies may, in some cases, hinder innovation. However, the authors state that educational policies can convince teachers to take steps toward innovations instead of preventing them when pointed in the right direction. We agree with this recommendation and suggest planning supportive measures for post-Covid-19 innovative work of teachers on the national, municipality, school, and teacher levels.

The present study's limitation is the small number of interviewed teachers, but the strength is that participants represent new and experienced teachers, from upper and lower primary schools of different sizes and from different parts of Finland, providing a balanced view of school practices and their enablers. This study provides a good foundation for studying school practices affected by Covid-19 and confirming previous research results regarding the need for innovative work of teachers. Further studies are required to examine how the novel practices innovated during distance education are applied and disseminated in schools currently and in the future. Further studies are also needed on teachers' innovative digipedagogical competence development - they should not be limited to assessing current competence levels but also focus on finding key factors that support or hinder the development of such competences for individual teachers and the whole school community. 


\section{Acknowledgements}

This research was supported by Innokas Network (www.innokas.fi), and the Strategic Research Council [grant numbers 312527 and 336064] of the Academy of Finland (Growing Mind, www.growingmind.fi).

\section{References}

Ahtiainen, R., Asikainen, M. S., Heikonen, L., Hienonen, N., Hotulainen, R., Lindfors, P., Lindgren, E. P., Lintuvuori, M., Oinas, S., Rimpelä, A., \& Vainikainen, M-P. (2020). Koulunkäynti, opetus ja hyvinvointi kouluyhteisössä koronaepidemian aikana: Ensitulokset [Schooling, teaching and wellbeing in the school community during the pandemc: First results]. Helsingin yliopisto: Koulutuksen arviointikeskus. https://www.helsinki.fi/fi/uutiset/koulutus-kasvatus-ja-oppiminen/koronakevatkuormitti-huoltajia-ja-opettajia-oppilaiden-kokemukset-etaopetuksesta-vaihtelivat Arnesen, K. T., Hveem, J., Short, C. R., West, R. E., \& Barbour, M. K. (2019). K-12 online learning journal articles: Trends from two decades of scholarship. Distance Education, 40(1), 32-53. https://doi. org/10.1080/01587919.2018.1553566

Barras, R. (1986). Towards a theory of innovation in services. Research Policy, 15(4), 161-173. Barras, R. (1990). Interactive innovation in financial and business services. The vanguard of the service revolution. Research Policy, 19(3), 215-237.

Cavanaugh, C. S., Barbour, M. K., \& Clark, T. (2009). Research and practice in K-12 online learning: A review of open access literature. The International Review of Research in Open and Distributed Learning, 10(1). https://doi.org/10.19173/irrodl.v10i1.607

Cavanaugh, C., \& Clark, T. (2007). The landscape of K-12 online learning. In C. Cavanaugh \& B. Blomeyer (Eds.), What works in K-12 online learning (pp. 521-542). International Society for Technology in Education.

Donaldson, J. (2020). Building a digitally enhanced community of practice. Information and Learning Sciences. Ahead-of-print. https://doi.org/10.1108/ILS-04-2020-0066.

Elo, S., \& Kyngäs, H. (2008) The qualitative content analysis process. Journal of Advanced Nursing, $62(1), 107-115$.

Ertmer, P. A., Ottenbreit-Leftwich, A. T., \& Tondeur, J. (2014). Teachers' beliefs and uses of technology to support 21st-century teaching and learning. In H. Fives, \& M. G. Gill (Eds.), International handbook of research on teachers' beliefs (pp. 403-418). Routledge.

Flynn, P. (2020). DESIGN-ED: A pedagogical toolkit to support K-12 teachers' emergency transition to remote online education. Information and Learning Sciences. Ahead-of-print. https://doi.

org/10.1108/ILS-04-2020-0103.

Fullan, M. (2015). The new meaning of educational change (4th ed). Teachers College Press. Halinen, I., \& Jarvinen, R. (2008). Towards inclusive education: The case of FINLAND. Prospects, 38(1), 77-97. https://doi.org/ 10.1007/s11125-008-9061-2 
Iivari, N., \& Sharma, S., \& Ventä-Olkkonen, L. (2020). Digital transformation of everyday life - How COVID-19 pandemic transformed the basic education of the young generation and why information management research should care? International Journal of Information Management, 55(2), 102183. https://doi.org/10.1016/j.ijinfomgt.2020.102183 Ilomäki, L., \& Lakkala, M. (2020). Finnish upper secondary school students' experiences with online courses. Education in the North, 27(2), 73-91. https://doi.org/10.26203/jsaz-8714 Jayathirtha, G., Fields, D., Kafai, Y. B., \& Chipps, J. (2020). Supporting making online: The role of artifact, teacher and peer interactions in crafting electronic textiles. Information and Learning Sciences, 121(5/6), 381-39o. https://doi.org/10.1108/ILS-04-2020-0111

Karvi [FEEC]. (2020). Korona-aika on haastanut kouluja ja oppilaitoksia kehittämään uusia hyviä käytänteitä [The Corona era has challenged schools and colleges to develop new good practices]. Kansallinen arviointikeskus, Karvi https://karvi.fi/2020/11/17/korona-aika-on-haastanut-kouluja-jaoppilaitoksia-kehittamaan-uusia-hyvia-kaytanteita

Kopcha, T. J. (2012). Teachers' perceptions of the barriers to technology integration and practices with technology under situated professional development. Computers \& Education, 59(4), 1109-1121. https://doi.org/10.1016/j.compedu.2012.05.014

Korhonen, T., \& Lavonen, J. (2017). A New Wave of Learning in Finland: Get Started with Innovation! In S. Choo, D. Sawch, A. Villanueva, \& R. Vinz (Eds.), Educating for the $21^{\text {st }}$ Century: Perspectives, Policies and Practicies from Around the World (pp. 447-467). Springer. https://doi. org/10.1007/978-981-10-1673-8_24

Korhonen, T., Salo,L., Seitamaa, A., Sormunen, M., Kukkonen, M., \& Forsström, H. (2021). $21^{\text {st }}$ century curriculum reform in Finland: Teachers adopting programming into teaching. Manuscript submitted for publication.

Kotilainen, M-R. (2015). Itseohjautuvuuden tukeminen vieraan kielen etäopetuksessa: designperustainen oppimisympäristön kehittämistutkimus perusasteen 5.-6. luokilla [Supporting selfguided learning in distance learning of foreign languages. Development study of design-based learning environment in elementary school grades 5 and 6]. Lapin yliopisto. http://urn.fi/ URN:ISBN:978-952-484-808-4

Lapada, A., Miguel, F., Robledo, D. A., \& Alam, Z. (2020). Teachers' covid-19 awareness, distance learning education experiences and perceptions towards institutional readiness and challenges. International Journal of Learning, Teaching and Educational Research, 19(6), 127-144. https://doi. org/10.26803/ijlter.19.6.8

Lavonen, J. (2020). Curriculum and teacher education reforms in Finland that support the development of competences for the twenty-first century. In F. M. Reimers (Ed.), Audacious education purposes: How governments transform the goals of education systems (pp. 65-80). Springer. https://doi.org/10.1007/978-3-030-41882-3_3

Messmann, G., \& Mulder, R.H. (2014). Exploring the role of target specificity in the facilitation of vocational teachers' innovative work behaviour. Journal of Occupational and Organizational Psychology, 87(1), 80-101. https://doi.org/10.1111/joop.12035 
Mishra, P., \& Koehler, M.J. (2006). Technological pedagogical content knowledge: A framework for teacher knowledge. Teachers College Record, 108(6), 1017-1054. https://doi.org/10.1111/j.14679620.2006.00684.X

Mitleton-Kelly, E. (2003). Complex systems and evolutionary perspectives on organisations (1st ed.). Pergamon Press.

Mäkelä, T., Mehtälä, S., Clements, K., \& Seppä, J. (2020). Schools went online over one weekend: Opportunities and challenges for online education related to the covid-19 crisis. In Proceedings of EdMedia + Innovate Learning 2020 (pp. 77-85). Association for the Advancement of Computing in Education (AACE).

Niemi, H. M., \& Kousa, P. (2020). A case study of students' and teachers' perceptions in a Finnish high school during the covid pandemic. International Journal of Technology in Education and Science, 4(4), 352-369. https://doi.org/10.46328/ijtes.v4i4.167 OECD (2019). TALIS 2018 Results (Volume I): Teachers and school leaders as lifelong learners. TALIS, OECD Publishing. https://dx.doi.org/10.1787/1dobc92a-en Palvia, S., Aeron, P., Gupta, P., Mahapatra, D., Parida, R., Rosner, R., \& Sindhi, S. (2018). Online education: Worldwide status, challenges, trends, and implications. Journal of Global Information Technology Management, 21(4), 233-241. https://doi.org/10.1080/1097198X.2018.1542262 Rogers, E. M. (2003). Diffusion of innovations (5th ed.). Free Press. Saari A., \& Säntti J. (2018) The rhetoric of the 'digital leap' in Finnish educational policy documents. European Educational Research Journal, 17(3), 442-457. https://doi.org/10.1177/1474904117721373 Saldana, J. (2016). The coding manual for qualitative researchers (3rd ed.). Sage. Schleicher, A. (2020). The impact of covid-19 on education: insights from education at a glance 2020. OECD. https://www.oecd.org/education/the-impact-of-covid-19-on-education-insights-educationat-a-glance-2020.pdf

Shulman, L. S. (1986). Those who understand: Knowledge growth in teaching. Educational Researcher, 15(2), 4-14. https://doi.org/10.3102/0013189X015002004

Tanhua-Piiroinen, E. Kaarakainen, S.-S. Kaarakainen, M.-T., \& Viteli, J. (2020). Digiajan peruskoulu II [Primary and secondary level school in the digital era]. Valtioneuvoston selvitysja tutkimustoiminnan julkaisusarja 17/2020. https://julkaisut.valtioneuvosto.fi/bitstream/ handle/10024/162236/OKM_2020_17.pdf?sequence=1\&isAllowed $=y$ Tanhua-Piiroinen, E., Kaarakainen, S.-S. Kaarakainen, M.-T.,Viteli, J., Syvänen, A., \& Kivinen, A. (2019). Digiajan peruskoulu [Primary and secondary level school in the digital era]. Valtioneuvoston selvitys- ja tutkimustoiminnan julkaisusarja 6/2019. http://julkaisut.valtioneuvosto.fi/bitstream/ handle/10024/161383/6-2019-Digiajan\%2operuskoulu_.pdf? sequence=1\&isAllowed=y Thurlings, M., Evers, A. T., \& Vermeulen, M. (2015) Toward a model of explaining teachers' innovative behavior: A literature review. Review of Educational Research, 85(3), 430-471. https://doi. org/10.3102/0034654314557949

Tilson, D., Lyytinen, K., \& Sørensen, C. (2010). Digital infrastructures: The missing IS research agenda. Information Systems Research, 21(4), 748-759. 
Tirri, K (2018). The purposeful teacher. In R. Monyai (Ed.), Teacher education in the 21st century. IntechOpen. https://doi.org/10.5772/intechopen.83437

Vivitsou, M. (2019). Digitalisation in education, allusions and references. CEPS Journal, 9(3), 117-136. https://doi.org/10.26529/cepsj.706

Vähäsantanen, K. (2015). Professional agency in the stream of change: Understanding educational change and teachers' professional identities. Teaching and Teacher Education, 47, 1-12. https://doi. org/10.1016/j.tate.2014.11.006

White, D. G., \& Levin, J. A. (2016). Navigating the turbulent waters of school reform. Guided by complexity theory. Complicity: An International Journal of Complexity and Education, 13(1), 43-8o. https://doi.org/10.29173/cmplct24566

\section{Biographical note}

Tima Korhonen, $\mathrm{PhD}$, is a university lecturer for Learning Innovations in Digital Society at the Faculty of educational sciences, University of Helsinki. She is the head of the nationwide Innokas Network organizing Innovation Education activities in 750 Finnish schools. Her research interests lie in the wide landscape of 21st century learning and the development of school practice, with special focus on the practical opportunities in digital technology and Innovation Education.

LAUra SALO, MEd, works as a project manager at the Faculty of educational sciences, University of Helsinki. She manages projects for the nationwide Innokas Network organizing Innovation Education activities in Finnish schools. Her research interests are centered on digitalization in education, teacher professional learning, the creative use of technology in education and 21st century competence development in schools.

LEENU JUUROLA, MEd, works as a project manager at the Faculty of educational sciences, University of Helsinki. She manages projects focused on the Innovative school model and teacher professional development. Her research interests include studying co-creation methods in professional networks and research-practice partnerships in school development projects.

Johanna Airaksinen, BEd, works as a research assistant at the Faculty of educational sciences, University of Helsinki, in the field of school development and teachers' transformative and digital agency. Her research interests include organization development, team dynamics and complex social systems. 